\title{
Expression profile of BAFF in peripheral blood from patients of IgA nephropathy: Correlation with clinical features and Streptococcus pyogenes infection
}

\author{
NUOYAN ZHENG ${ }^{1,2^{*}}$, JINJIN FAN $^{2 *}$, BING WANG $^{3}$, \\ DONGXIAN WANG ${ }^{1,2}$, PINNING FENG ${ }^{4}$, QIONGQIONG YANG ${ }^{2}$ and XUEQING YU ${ }^{2}$ \\ ${ }^{1}$ Translational Medical Center; ${ }^{2}$ Department of Nephrology, The First Affiliated Hospital of Sun Yat-sen University; \\ ${ }^{3}$ International Travel Health Care Center, Entry \& Exit Inspection and Quarantine Bureau of Guangdong Guangzhou; \\ ${ }^{4}$ Clinical Laboratory, The First Affiliated Hospital of Sun Yat-sen University, Guangzhou, Guangdong 510000, P.R. China
}

Received January 5, 2016; Accepted December 22, 2016

DOI: $10.3892 / \mathrm{mmr} .2017 .6190$

\begin{abstract}
B cells are critically important for the pathogenesis of $\operatorname{Ig}$ A nephropathy ( $\operatorname{Ig} A N)$. The present study aimed to investigate the abundance of $\mathrm{B}$ cell activating factor (BAFF), which belongs to the tumor necrosis factor superfamily, in the peripheral blood of patients with IgAN. The different forms of BAFF in peripheral blood and its association with clinical features and immunological factors were analyzed. mRNA levels of BAFF and other associated genes in the peripheral blood mononuclear cells (PBMCs) of patients with IgAN and controls were analyzed by quantitative polymerase chain reaction. Cellular BAFF proteins in PBMCs and plasma soluble BAFF proteins were measured by western blot analysis and ELISA, respectively. PBMCs from patients were stimulated with Streptococcus pyogenes (S. pyogenes) ex vivo for the BAFF
\end{abstract}

Correspondence to: Professor Xueqing Yu, Department of Nephrology, The First Affiliated Hospital of Sun Yat-sen University, 58 Zhongshan Er Road, Yuexiu, Guangzhou, Guangdong 510000, P.R. China

E-mail: yuxq@mail.sysu.edu.cn

Dr Nuoyan Zheng, Translational Medical Center, The First Affiliated Hospital of Sun Yat-sen University, 58 Zhongshan Er Road, Yuexiu, Guangzhou, Guangdong 510000, P.R. China

E-mail: zhnuoy@mail.sysu.edu.cn

*Contributed equally

Abbreviations: IgAN, IgA nephropathy; BAFF, B cell activation factor; APRIL, a proliferation inducing ligand; TACI, transmembrane activator and calcium modulator cyclophilin ligand interactor; BCMA, B cell maturation antigen; BAFF-R, BAFF receptor; PBMCs, peripheral blood mononuclear cells; $\mathrm{MCD}$, minimal change disease; MN, membranous nephropathy; LN, lupus nephritis; TLR, Toll-like receptor

Key words: IgA nephrology, B cell activation factor, toll-like receptors, Streptococcus pyogenes secretion assay. The data demonstrated that, although mRNA levels of BAFF in PBMC were not significantly increased in patients with $\operatorname{IgAN}$, they were positively associated with those of a proliferation inducing ligand (APRIL), Toll-like receptor (TLR)2, TLR4 and TLR7. The cellular BAFF protein in PBMCs was not upregulated. Plasma BAFF protein levels in patients with $\operatorname{IgAN}(n=76)$ were significantly decreased compared with controls. However, plasma BAFF levels were positively associated with serum creatinine, proteinuria, uric acid and group A Streptococcus infection index in patients with IgAN. In patients with IgAN, plasma BAFF concentrations were markedly higher in those with more severe renal tubular atrophy/interstitial fibrosis and global glomerulosclerosis. Furthermore, BAFF production in PBMCs of patients with IgAN was increased following $S$. pyogenes stimulation ex vivo. In conclusion, plasma BAFF levels in patients with IgAN were associated with renal function and disease activity. $S$. pyogenes infection was closely associated with BAFF production in patients with IgAN.

\section{Introduction}

$\operatorname{Ig} \mathrm{A}$ nephropathy $(\operatorname{Ig} \mathrm{AN})$ is characterized by the mesangial deposit of $\operatorname{IgA}$-immune complex in the kidneys of patients (1). The dimeric IgA-secreting-bone marrow $\mathrm{B}$ cells are more abundant in patients with $\operatorname{IgAN}(2)$ and evidence from animal models suggests that CD19+ B cells are essential for the pathogenesis of $\operatorname{IgAN}(3,4)$. B cell activation factor (BAFF) and a proliferation inducing ligand (APRIL) are two important factors for B cell homeostasis (5). BAFF is a pivotal factor for B cell survival, proliferation and maturation $(6,7)$. BAFF Tg mice develop an IgAN-like nephritic syndrome, in which IgA production is essential for renal pathology (8). APRIL controls Ig class-switch recombination towards IgA subclass and gene polymorphism of the APRIL gene is associated with susceptibility to $\operatorname{IgAN}(9,10)$. Two different transcript variants (NM_006573.4 and NM_001145645.2) exist for the human BAFF gene, resulting in two isoforms of 286aa and 267aa, respectively. Following protein translation and N-glycosylation, Isoform 1 (NP_006564.1) exists 
either as full-length membrane-associated form, or as a short secreted soluble protein which is cleaved at Arg133/Asn134 by proteinase $(11,12)$. However, Isoform 2 (NP_001139117.1) is not subject to cleavage following translation (12). BAFF and APRIL share two receptors: Transmembrane activator and calcium modulator cyclophilin ligand interactor (TACI) and B cell maturation antigen (BCMA), whereas BAFF also binds to its unique receptor: BAFF receptor (BAFF-R or BR3) $(13,14)$. All three receptors are type III transmembrane receptors, belonging to the superfamily of tumor necrosis factor receptors (13) and are predominantly expressed by different subsets of B cells (14).

BAFF is closely associated with autoimmune diseases including systemic lupus erythematosus, rheumatoid arthritis and Sjogren's syndrome, and has become a key therapeutic target for several autoimmune diseases $(15,16)$. The serum levels of BAFF are reported to be elevated in autoimmune diseases (17-20), which cause exaggerated Ig synthesis and later immune imbalance $(21,22)$. Previously, several groups have provided data of serum BAFF levels in IgAN. Xin et al (23) determined that serum BAFF proteins were more abundant in patients with $\operatorname{IgAN}$ and were associated with kidney function and renal histopathology. Li et al (24) identified that serum BAFF levels were significantly higher in patients with IgAN and were associated with Toll-like receptor (TLR)-9 mRNA levels. However, McCarthy et al (25) determined that BAFF levels were not elevated in patients with IgAN based on data from two cohorts. As BAFF expression data in peripheral blood of patients with $\operatorname{IgAN}$ was not consistent and the combined association of BAFF expression with disease activity was unclear, the present study presented detailed data on BAFF expression in peripheral blood system of patients with IgAN from several aspects: mRNA levels in peripheral blood mononuclear cells (PBMCs), cellular protein levels in PBMCs and plasma protein levels. The capacity of PBMCs to secrete BAFF proteins following the activation of TLRs and Streptococcus pyogenes (S. pyogenes) stimulation was also examined to explore the possible role of BAFF in IgAN.

\section{Materials and methods}

Study groups. Verified patients with IgAN and with the clinical features of primary IgAN were enrolled in the First Affiliated Hospital of Sun Yat-sen University (Guangzhou, China). Healthy donors and patients with nephritis who were diagnosed as primary minimal change disease (MCD) or primary membranous nephropathy (MN) were also included as disease controls in the present study. All recruited donors were from the Chinese Han population. All healthy participants were negative for hematuria and proteinuria, and possessed normal serum creatinine content and liver function. All of them provided written informed consent. Patients diagnosed as end stage renal disease were excluded from the current study. None of the patients had been treated with steroids and/or immunosuppressive drugs within one year of the study. All donors were free of clinical infection symptoms 4 days before and 3 days following the day of the blood sample test, nor did they suffer from systemic infection within one month of the test. The present study obtained approval from the Ethics
Review Committee of the First Affiliated Hospital of Sun Yat-sen University (Guangzhou, China) and was conducted in accordance with the guidelines proposed in the Declaration of Helsinki.

The renal histopathology of patients with $\operatorname{Ig} \mathrm{AN}$ was categorized according to the Oxford classification (26). Renal histopathology from all patients was scored by two renal pathologists blinded to the clinical data for the four pathological variables: The mesangial hypercellularity (M), the segmental glomerulosclerosis $(\mathrm{S})$, the endocapillary hypercellularity $(\mathrm{E})$ and the tubular atrophy/interstitial fibrosis (T). Global glomerulosclerosis was also scored according to the proportion of the total number of glomeruli that exhibited glomerulosclerosis: G0, 0-25\%; G1, 26-50\%; G2, >50\% (27).

Main reagents. The reverse transcription kit (cat. no. RR014A) and Real-Time Master kit (cat. no. DRR014A) were purchased from Takara Bio, Inc. (Otsu, Japan); DNaseI (cat. no. AM2235) from Thermo Fisher Scientific, Inc. (Waltham, MA, USA). BAFF antibody for western blot analysis (cat. no. ab65360) from Abcam (Cambridge, UK); BAFF capture antibody for ELISA (cat. no. AF124) from R\&D Systems (Minneapolis, MN, USA); BAFF detection antibody for ELISA (cat. no. RHF910B) from Antigenix America (Huntington Station, NY, USA); lipopolysaccharide (cat. no. L2880) from Sigma-Aldrich (Merck Millipore, Darmstadt, Germany); Pam3CSK4 (cat. no. ALK-165-006-M002) from Enzo Life Science, Inc. (Farmingdale, NY, USA); and, CpG2395 (cat. no. Ctrl-2395) from Thermo Fisher Scientific, Inc.

Design of primers. The cDNA nucleotide sequences of BAFF (NCBI RefSeq NM_006573.4), APRIL (NCBI RefSeq NM_003808.3), TACI (NCBI RefSeq NM_012452.2), BCMA (NCBI RefSeq NM_001192.2), BAFF-R (NCBI RefSeq NM_052945.3), TLR2 (NCBI RefSeq NM_003264.3), TLR4 (NCBI RefSeq NM_138554.4), TLR7 (NCBI RefSeq NM_016562.3), TLR9 (NCBI RefSeqNM_017442.3), glyceraldehyde-3-phosphate dehydrogenase (GAPDH; NCBI RefSeq NM_002046.4) were acquired from the NCBI database (https://www.ncbi.nlm.nih.gov). Primers for each gene were designed by Primer 3.0 software (http://frodo.wi.mit.edu) and confirmed with non-redundant sequence in human cDNA sequence database. BAFF, forward 5'-CGTTCAGGGTCC AGAAGAAA-3' and reverse5'-GTCCCATGGCGTAGGTCT TA-3'; APRIL, forward 5'-AGCCAGGTCCTGTTTCAAGA-3' and reverse 5'-ATGGAAGACACCTGCGCTAT-3'; BAFF-R, forward 5'-CCCTGGACAAGGTCATCATT-3' and reverse 5'-TCTTGGTGGTCACCAGTTCA-3'; BCMA, forward 5'-GCAGTGCTCCCAAAATGAAT-3' and reverse 5'-GTC CCAAACAGGTCCAGAGA-3'; TACI, forward 5'-CATCTC CTGAGGGACTGCAT-3' and reverse 5'-TGGTACCTTCCC GAGTTGTC-3'; TLR2, forward 5'-TGATGCTGCCATTCT CATTC-3' and reverse 5'-CGCAGCTCTCAGATTTACCC-3'; TLR4, forward 5'-TGAGCAGTCGTGCTGGTATC-3' and reverse 5'-CAGGGCTTTTCTGAGTCGTC-3'; TLR7, forward 5'-GATGCCTTCCAGTTGCGATA-3' and reverse 5'-TCCGTA TGGTTAACCCACCA-3'; TLR9, forward 5'-GGAAGGGAC CTCGAGTGTGA-3' and reverse 5'-AGCCAGTTGCAGTTC ACCAG-3'; GAPDH, forward 5'-GAGTCAACGGATTTG GTCGT-3' and reverse 5'-GACAAGCTTCCCGTTCTCAG-3'. 
Preparation of PBMCs and gene expression analysis. PBMCs from venous blood with anticoagulant EDTA-K2 were enriched by Ficoll-paque density centrifugation (700 x $g$ for $20 \mathrm{~min})$. Following centrifugation, cells were washed four times with PBS. Their viability was above $95 \%$ as observed with eosin red staining. Total RNA of PBMCs was extracted using TRIzol reagent following the manufacturer's protocols, then treated with DNase I digestion. A total of $200 \mathrm{ng}$ of RNA sample was subjected to reverse transcriptase reaction for 30 min incubation at $37^{\circ} \mathrm{C}$ with the cDNA synthesis kit DRR037A (Takara Bio, Inc., Otsu, Japan). The quantitative reaction system was prepared following the protocol of the quantitative polymerase chain reaction (PCR) kit and the reaction was performed for 40 cycles of $95^{\circ} \mathrm{C}$ for $30 \mathrm{sec}, 58^{\circ} \mathrm{C}$ for $30 \mathrm{sec}$ and $72^{\circ} \mathrm{C}$ for $30 \mathrm{sec}$ in an ABI7900 instrument (Applied Biosystems; Thermo Fisher Scientific, Inc.). The data were analyzed using SDS2.4 (Applied Biosystems; Thermo Fisher Scientific, Inc.) and Microsoft Excel software (Microsoft, Redmond, WA, USA). The relative gene expression was calculated with the $2^{-\triangle \Delta C q}$ method (28), using GAPDH as the internal control.

Detection of cellular BAFF protein in western blot analysis and plasma BAFF protein in ELISA. Proteins of PBMCs were extracted using RIPA buffer and lysates were separated in SDS-PAGE. The proteins were transferred onto nitrocellulose membranes, blocked with $5 \%$ dried milk and then incubated with anti-human BAFF antibody (1:200; cat no. Ab65360; Abcam) and secondary antibody (1:1,000; cat no. 711-035-152; Jackson Immuno Research Laboratories Inc., West Grove, PA, USA) for chemiluminescence development.

Plasma samples were diluted 10 times for BAFF ELISA. Briefly, 96-well plates coated with BAFF antibody $(1 \mu \mathrm{g} / \mathrm{ml}$; cat no. AF124, R\&D Systems, Inc.) were blocked with $1 \%$ $\mathrm{BSA}+1 \% \mathrm{FBS} / \mathrm{PBS}$ for $4 \mathrm{~h}$ at $37^{\circ} \mathrm{C}$. The wells were washed with PBS containing $0.05 \%$ Tween-20 (PBST) and incubated with the diluted sample or standard BAFF proteins at $4^{\circ} \mathrm{C}$ overnight. Following washing with PBST, the plates were then incubated sequentially with $100 \mu$ l biotinylated anti-human BAFF antibody $\left(0.1 \mu \mathrm{g} / \mathrm{ml}\right.$; cat no. RH910B; Antigenix America) at $37^{\circ} \mathrm{C}$ for $3 \mathrm{~h}$, then peroxidase-conjugated streptavidin in at $37^{\circ} \mathrm{C}$ for $60 \mathrm{~min}$. The color was developed with tetramethylbenzidine and stopped by adding $100 \mu \mathrm{l} 2 \mathrm{~N} \mathrm{HCl}$. The optical density of each well was measured by spectrophotometer (Spectra Max M5; Molecular Devices, LLC, Sunnyvale, CA, USA) at OD450 nm.

Secretion of BAFF proteins from PBMCs upon TLR ligands and $S$. pyogenes stimulation ex vivo. PBMCs isolated from Ficoll-paque density centrifugation were suspended in complete 1640 medium (RPMI-1640 medium, 10\% FBS, $100 \mu \mathrm{g} / \mathrm{ml}$ penicillin and streptomycin, $2 \mathrm{mM}$ L-glutamine, $100 \mathrm{mM}$ sodium pyruvate, $55 \mathrm{mM} \beta$-mercaptoethanol; all supplied by Thermo Fisher Scientific, Inc.) and then cultured at $37^{\circ} \mathrm{C}$ in a $5 \% \mathrm{CO}_{2}$ incubator at a density of $2.5 \times 10^{5} \mathrm{PBMCs} /$ well in a 96 -well plate. The cells were stimulated with different TLR ligands (TLR2-Pam3CSk4, $1 \mu \mathrm{g} / \mathrm{ml}$; TLR4-LPS, $1 \mu \mathrm{g} / \mathrm{ml}$; and TLR9-CpG, $5 \mu \mathrm{g} / \mathrm{ml})$ or heat-inactivated $S$. pyogenes $\left(2 \times 10^{7} \mathrm{CFU} / \mathrm{ml}\right)$. Following incubation for $72 \mathrm{~h}$, the supernatant of the cell culture was harvested and concentrated for BAFF ELISA. Stimulated PBMCs were also collected for analysis of gene expression in quantitative PCR. For preparation of $S$. pyogenes, a single colony was cultured in tryptone yeast medium plus $0.2 \%$ glucose overnight, then subcultured for another $48 \mathrm{~h}$ in $5 \% \mathrm{CO}_{2}$ incubator at $37^{\circ} \mathrm{C}$. The specificity of $S$.pyogenes was additionally confirmed with S. pyogenes specific primers in PCR as previously performed by Liu et al (29). The CFU of bacteria was counted on a blood agar plate. The harvested bacteria were inactivated at $70^{\circ} \mathrm{C}$ for $1 \mathrm{~h}$ then stored at $-80^{\circ} \mathrm{C}$ for later use.

Statistical analysis. Data were expressed as the mean \pm standard error and tested with Student's t-test. For data where three and more groups were involved, a one-way analysis of variance analysis was performed and additional post hoc tests were conducted when $\mathrm{P}<0.05$. The correlation was tested with Pearson's correlation coefficients and presented with scatter plot. Statistical analyses were performed with SPSS software, version 18.0 (SPSS, Inc., Chicago, IL, USA). All statistical assessments were two-sided using a significance value of $\mathrm{P}<0.05$, which was considered to indicate a statistically significant difference.

\section{Results}

The $m R N A$ levels of BAFF, APRIL and their receptors in PBMCs of patients with IgAN. For mRNA level analysis, 51 healthy donors, 44 patients with IgAN and 22 disease controls (14 cases of MN, 8 cases of MCD) were enrolled. The demographic and clinical parameters are presented in Table I. The mRNA levels of BAFF, APRIL, BCMA, TACI and BAFF-R in PBMCs were analyzed by quantitative PCR as presented in Fig. 1A. The relative BAFF mRNA levels demonstrated a small but not significant change in patients with IgAN compared with healthy controls $(0.044 \pm 0.002$ vs. $0.040 \pm 0.002, \mathrm{P}=0.063)$ and disease controls $(0.044 \pm 0.002$ vs. $0.040 \pm 0.002, \mathrm{P}=0.16)$. The mRNA levels of APRIL were not significantly altered in patients with $\operatorname{IgAN}$, as compared with healthy or disease controls. Notably, mRNA levels of BAFF-R, TACI and BCMA were all increased in the individuals with $\operatorname{IgAN}, \mathrm{MCD}$ and $\mathrm{MN}$, as compared with the healthy controls. Expression of BAFF-R was increased by $42.6 \%(\mathrm{P}=0.096)$ in patients with $\operatorname{IgAN}$ and by $86.3 \%$ $(\mathrm{P}<0.0001)$ in disease controls. Expression of TACI was increased by $25.9 \%(\mathrm{P}=0.083)$ in patients with $\operatorname{IgAN}$ and by $52.4 \%(\mathrm{P}=0.007)$ in disease controls. Expression of BCMA was increased by $26.7 \%(\mathrm{P}=0.273)$ in patients with $\mathrm{IgAN}$ and by $85.4 \%(\mathrm{P}<0.0001)$ in disease controls.

The association among $m R N A$ levels of BAFF, APRIL, their receptors and TLRs. Among the mRNA levels of BAFF, APRIL, BAFF-R, BCMA and TACI in patients with IgAN, a marked positive association existed between BAFF and APRIL mRNA levels ( $\mathrm{r}=0.60, \mathrm{P}<0.0001)$. The mRNA abundance of BAFF was not significantly correlated with those of its receptors (BAFF-R, BCMA and TACI) in either patients with IgAN or disease controls (Fig. 1B). The positive association between mRNA levels of BAFF and APRIL was also observed in disease controls ( $r=0.60, P=0.003$, Fig. $1 C)$, however not in healthy controls $(\mathrm{r}=0.084, \mathrm{P}=0.54)$. 
Table I. Clinical and demographic features of patients with IgAN and disease controls.

\begin{tabular}{|c|c|c|c|c|c|c|}
\hline \multirow[b]{2}{*}{ Feature } & \multicolumn{3}{|c|}{ BAFF mRNA levels } & \multicolumn{3}{|c|}{ BAFF protein levels in plasma } \\
\hline & Healthy controls & IgAN & Disease controls & Healthy controls & IgAN & Disease controls \\
\hline \multicolumn{7}{|l|}{ Gender } \\
\hline Male & 24 & 19 & 13 & 25 & 39 & 24 \\
\hline Female & 27 & 25 & 9 & 42 & 37 & 22 \\
\hline Age (year) & $33.1 \pm 8.7$ & $34.2 \pm 9.3$ & $37.3 \pm 12.5$ & $34.3 \pm 9.1$ & $33.3 \pm 9.9$ & $79.0 \pm 31.9$ \\
\hline Serum creatinine $(\mu \mathrm{M})$ & & $87.8 \pm 41.0$ & $70.6 \pm 18.1$ & & $104.5 \pm 61.9$ & $79.0 \pm 31.9$ \\
\hline 24 h-proteinuria $(\mathrm{g} / 24 \mathrm{~h})$ & & $1.16 \pm 1.4$ & $5.12 \pm 4.78$ & & $0.95 \pm 0.97$ & $4.06 \pm 4.13$ \\
\hline Serum uric acid $(\mu \mathrm{M})$ & & $362.7 \pm 115.5$ & $423.9 \pm 80.6$ & & $404.7 \pm 123.0$ & $380.4 \pm 91.3$ \\
\hline CKD I & & 33 & 18 & & 45 & 34 \\
\hline CKD II & & 5 & 3 & & 10 & 8 \\
\hline CKD III & & 5 & 1 & & 13 & 3 \\
\hline CKD IV & & 1 & 0 & & 8 & 1 \\
\hline
\end{tabular}

IgAN, IgA nephropathy; BAFF, B cell activation factor; CKD, chronic kidney disease.

Table II. Association of BAFF expression levels with clinical parameters in patients with IgAN.

\begin{tabular}{|c|c|c|c|c|}
\hline \multirow[b]{2}{*}{ Feature } & \multicolumn{2}{|c|}{ BAFF mRNA levels in PBMCs } & \multicolumn{2}{|c|}{ BAFF protein levels in plasma } \\
\hline & Pearson $\mathrm{r}$ & P-value & Pearson $\mathrm{r}$ & P-value \\
\hline Age (year) & -0.16 & 0.30 & 0.019 & 0.87 \\
\hline Serum creatinine $(\mu \mathrm{Mol} / \mathrm{l})$ & -0.014 & 0.93 & 0.25 & $0.03^{\mathrm{a}}$ \\
\hline 24 h-proteinuria (g/24 h) & -0.02 & 0.90 & 0.25 & $0.03^{\mathrm{a}}$ \\
\hline Serum uric acid $(\mu \mathrm{Mol} / \mathrm{l})$ & -0.28 & 0.10 & 0.27 & $0.02^{\mathrm{a}}$ \\
\hline Serum $\operatorname{IgA}(g / l)$ & -0.05 & 0.76 & -0.17 & 0.18 \\
\hline Serum IgG (g/l) & -0.06 & 0.72 & -0.20 & 0.11 \\
\hline Serum C3 (g/l) & -0.11 & 0.53 & -0.06 & 0.63 \\
\hline $\mathrm{CRP}(\mathrm{mg} / \mathrm{l})$ & -0.22 & 0.20 & -0.11 & 0.37 \\
\hline $\mathrm{SAA}(\mathrm{mg} / \mathrm{l})$ & -0.12 & 0.48 & -0.17 & 0.17 \\
\hline $\operatorname{ASO}(\mathrm{kU} / \mathrm{l})$ & -0.22 & 0.18 & -0.03 & 0.81 \\
\hline Anti-DNase B (IU/ml) & 0.17 & 0.31 & 0.25 & $0.04^{\mathrm{a}}$ \\
\hline
\end{tabular}

BAFF, B cell activation factor; IgAN, IgA nephropathy; PBMCs, peripheral blood mononuclear cells; C3, complement 3; CRP, C-reactive protein; SAA, Serum amyloid A protein; ASO, anti-streptolysin $\mathrm{O}$. ${ }^{\mathrm{P}} \mathrm{P}<0.05$.

For correlation among mRNA levels of BAFF and those of TLRs, it was identified that BAFF mRNA levels were positively associated with TLR2 $(\mathrm{r}=0.40, \mathrm{P}=0.037)$, TLR4 $(\mathrm{r}=0.42, \mathrm{P}=0.032)$ and TLR7 $(\mathrm{r}=0.52, \mathrm{P}=0.083) \mathrm{mRNA}$ levels in patients with $\operatorname{IgAN}$, but not with TLR9 mRNA levels in patients with IgAN (Fig. 2A). BAFF mRNA levels were not significantly associated with TLR2/4/7/9 mRNA levels in disease controls (Fig. 2B). However, the small sample size $(n<20)$ may underestimate the possible correlation of BAFF mRNA with TLRs mRNA in disease controls.

To analyze the possible association between BAFF expression and clinical parameters, 10 parameters representing renal function and immunological response were included for statistical analysis. Statistical data demonstrated that there is no significant correlation between BAFF mRNA levels and age, serum creatinine, 24 -h proteinuria, serum uric acid, C-reactive protein, serum $\mathrm{C} 3$ protein, serum amyloid A, anti-streptolysin O, anti-DNase B titer, serum $\mathrm{IgA}$ or serum $\mathrm{IgG}$ in patients with $\operatorname{Ig} \mathrm{AN}$ (Table II).

$B A F F$ protein levels in PBMCs and in plasma of patients with $I g A N$. For the detection of cellular BAFF proteins in PBMCs, 23 healthy controls and 21 patients with IgAN were enrolled for this assay. Proteins extracted from PBMCs were analyzed by western blot analysis to detect the cellular BAFF proteins. Two clear bands at $\sim 35 \mathrm{kDa}$ for BAFF protein in western blot analysis were detected (Fig. 3A). The detected protein larger in size than predicted was possibly due to $\mathrm{N}$-glycosylation of 
A

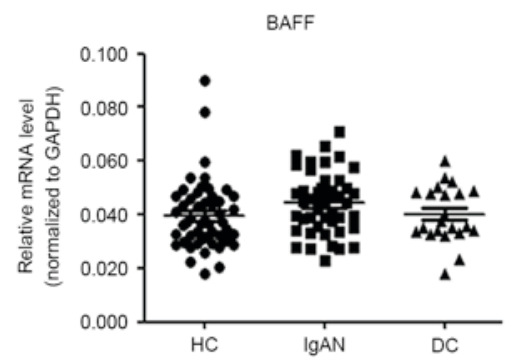

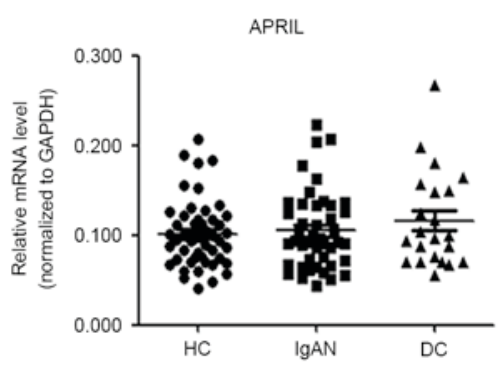
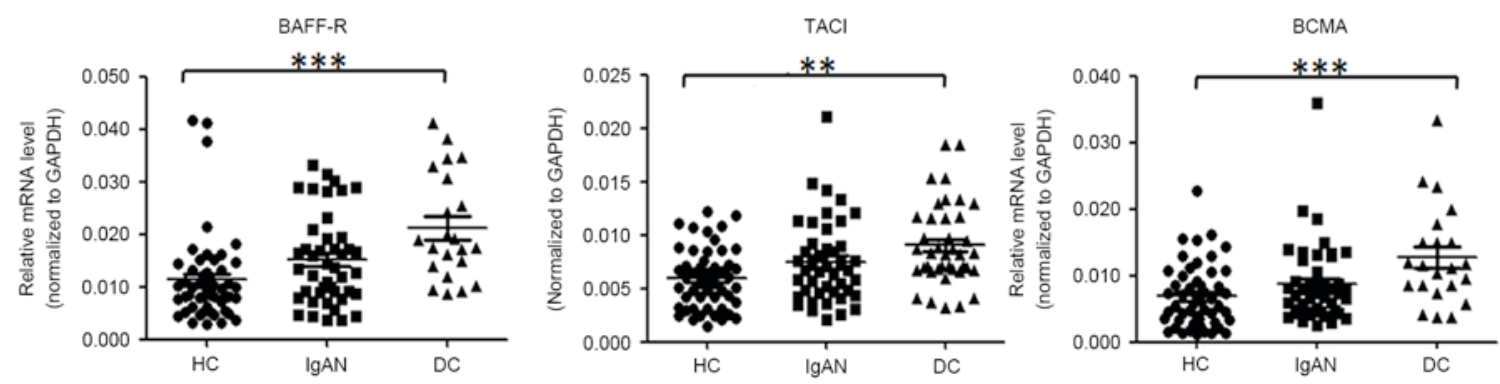

B

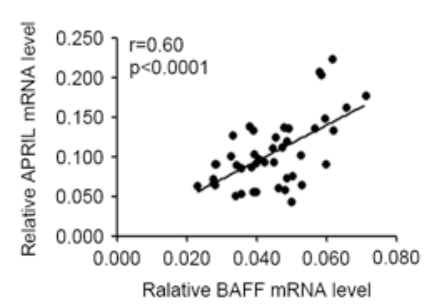

Ralative BAFF mRNA level

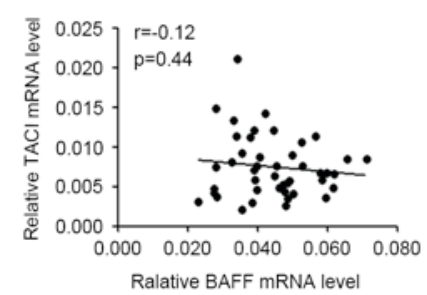

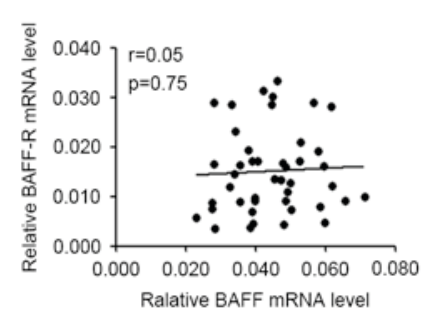

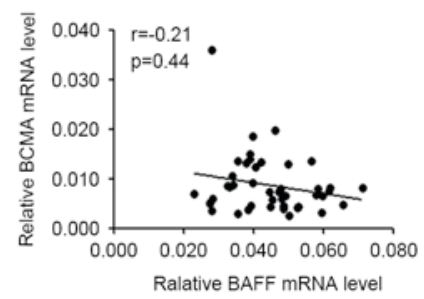

$\mathrm{C}$
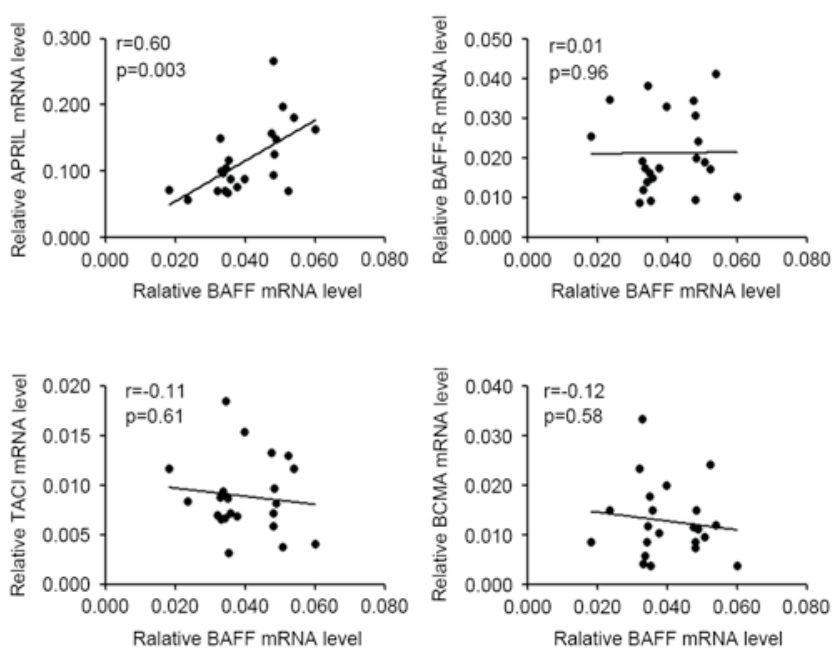

Figure 1. BAFF mRNA levels were not significantly elevated in the PBMCs of patients with IgAN. (A) PBMCs of donors were prepared by Ficoll-paque density centrifugation and subjected to quantitative PCR analysis for target gene analysis. The horizontal line represents the mean value of each group. HC, healthy controls; IgAN, patients with IgAN; DC, disease controls (MCD/MN). (B) Correlation of BAFF mRNA levels with APRIL, BAFF-R, TACI, BCMA mRNA levels in patients with IgAN. (C) Correlation of BAFF mRNA levels with APRIL, BAFF-R, TACI, BCMA mRNA levels in disease controls. ${ }^{*} \mathrm{P}<0.05,{ }^{* *} \mathrm{P}<0.01$, ${ }_{* * * *} \mathrm{P}<0.001$. BAFF, B cell activation factor; PBMCs, peripheral blood cells; IgAN, IgA nephropathy; PCR, polymerase chain reaction; MCD, minimal change disease; MN, membranous nephropathy; APRIL, a proliferation inducing ligand; BAFF-R, BAFF receptor; TACI, transmembrane activator and calcium modulator cyclophilin ligand interactor; BCMA, B cell maturation antigen; GAPDH, glyceraldehyde-3-phosphate dehydrogenase.

BAFF protein as previously reported $(30,31)$. When normalized to GAPDH, the abundance of BAFF protein was not significantly altered in the PBMCs of patients with IgAN when compared with healthy controls (Fig. 3B).

For the detection of BAFF proteins in plasma, 67 healthy donors, 76 patients with IgAN, 48 disease controls and 20 patients with lupus nephritis (LN) were recruited. Each plasma sample were repeated at least twice in ELISA. Serum BAFF levels have been reported to be remarkably enhanced in patients with $\mathrm{LN}(32,33)$, thus these samples were used as the positive control $(3,291 \pm 309 \mathrm{pg} / \mathrm{ml})$ in the present study. However, plasma BAFF proteins in patients with IgAN were significantly fewer when compared with those in healthy controls $(2,049 \pm 32.9 \mathrm{pg} / \mathrm{ml}$ vs. $2,422 \pm 54.2 \mathrm{pg} / \mathrm{ml}, \mathrm{P}<0.0001)$ and in disease controls $(2,049 \pm 32.9 \mathrm{pg} / \mathrm{ml}$ vs. $2,220 \pm 70.4 \mathrm{pg} / \mathrm{ml}$,
$\mathrm{P}=0.014$; Fig. 3C). Meanwhile, the plasma BAFF levels were not associated with BAFF mRNA levels in patients with IgAN $(\mathrm{n}=27$; Fig. 3D). Plasma BAFF protein concentrations in female and male patients with IgAN were not significantly different $(2,049 \pm 52.2 \mathrm{pg} / \mathrm{ml}$ vs. $2,057 \pm 41.5 \mathrm{pg} / \mathrm{ml}, \mathrm{P}=0.91)$.

Despite the evidence that plasma levels of BAFF were decreased in patients with IgAN, plasma BAFF levels were positively associated with serum creatinine $(\mathrm{r}=0.25, \mathrm{P}=0.03)$, 24-hproteinuria $(r=0.25, P=0.03)$, serum uric acid $(r=0.27$, $\mathrm{P}=0.02)$ and anti-DNase $\mathrm{B}$ titer $(\mathrm{r}=0.25, \mathrm{P}=0.04)$ in patients with IgAN (Table II), which was not observed in disease controls (data not shown). Anti-DNase B titer is an index for group A streptococcus (GAS) infection. S. pyogenes is an important species of gram-positive bacterium that can cause bacterial pharyngitis and the development of post-streptococcal 
A
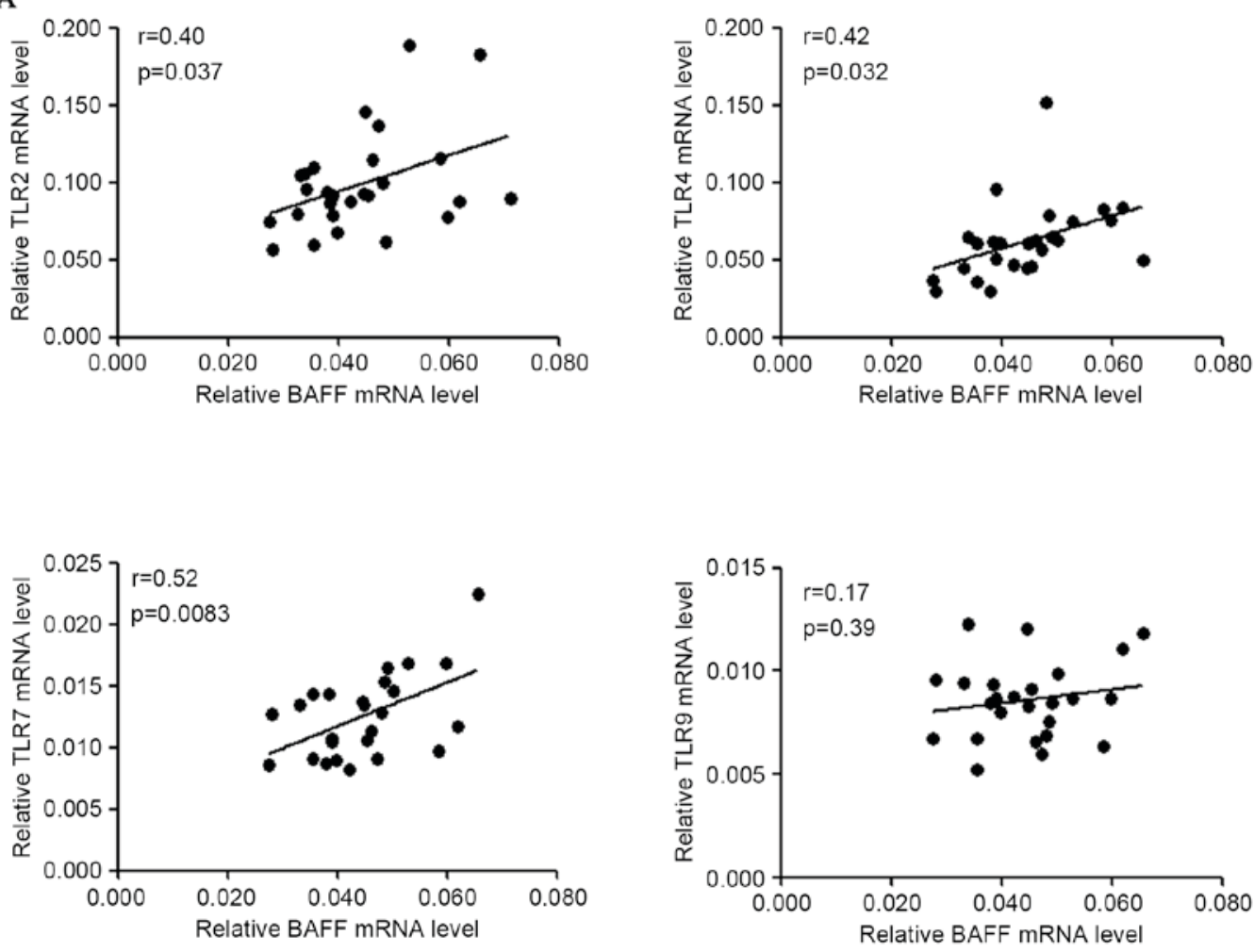

B
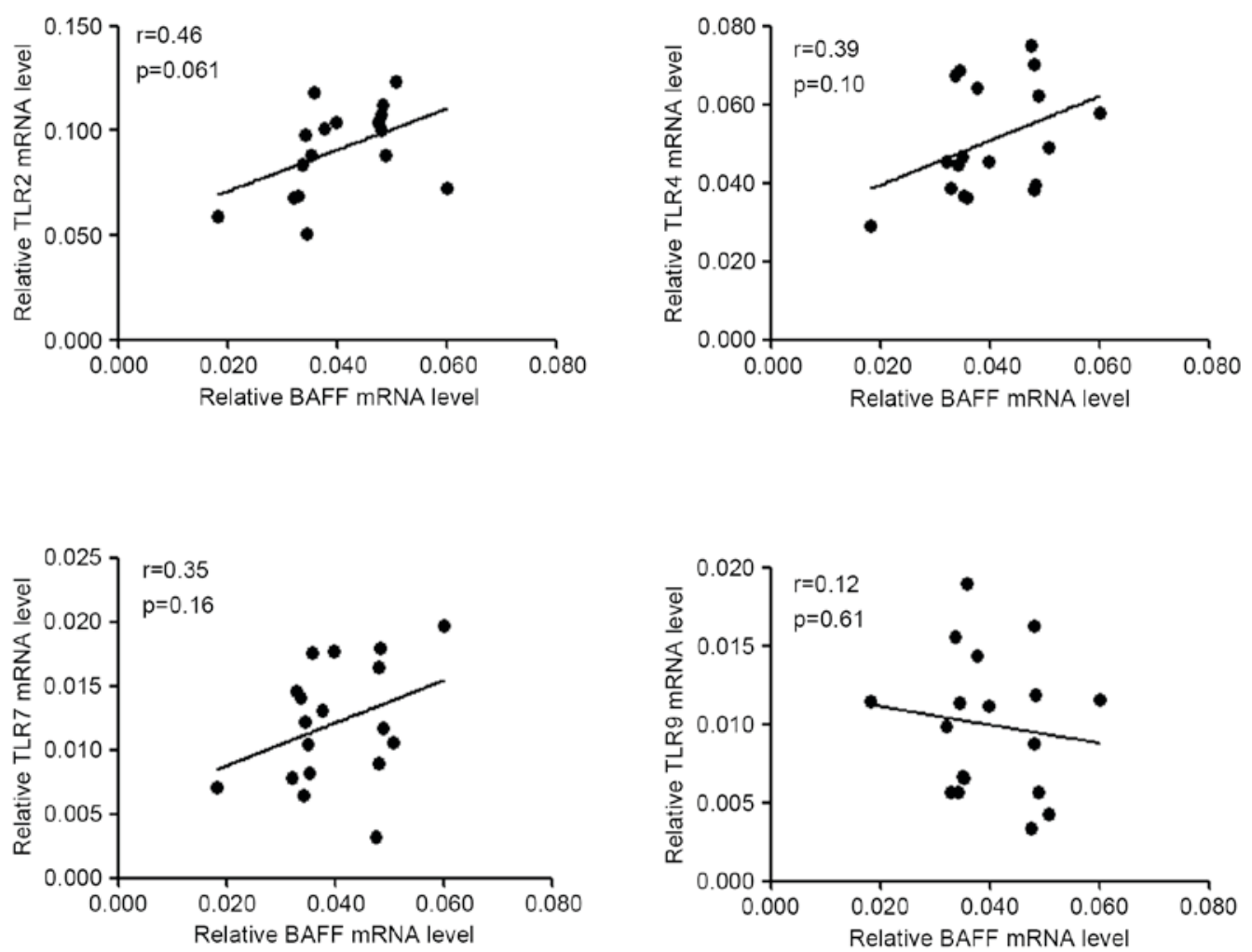

Figure 2. Correlation of BAFF mRNA levels with TLR2, TLR4, TLR7, TLR9 mRNA levels in PBMCs from patients with (A) IgAN and (B) disease controls. BAFF, B cell activation factor; TLR, Toll-like receptor; PBMCs, peripheral blood mononuclear cells.

infection including acute glomerulonephritis, rheumatic fever and reactive arthritis (34). The association of plasma BAFF concentrations and renal histopathology in patients with IgAN was also analyzed (Fig. 4). It was determined that plasma BAFF protein levels were significantly higher in patients with a high score in tubular atrophy/interstitial fibrosis and global 
A

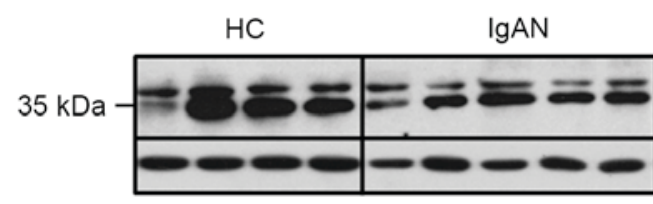

BAFF

GAPDH

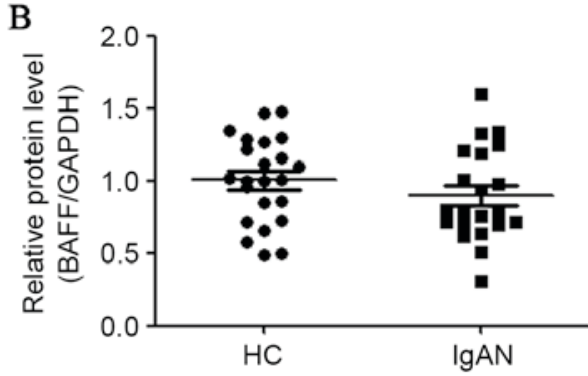

$\mathrm{D}$

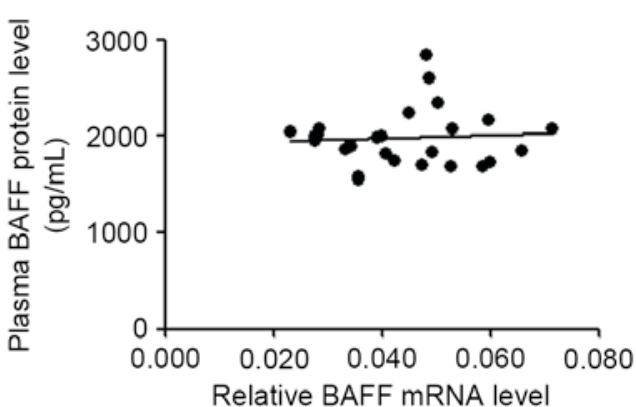

Figure 3. Detection of BAFF proteins in PBMCs and plasma of patients with IgAN. (A) Cellular BAFF proteins detected in PBMCs of patients with IgAN Proteins were isolated from PBMCs of patients with IgAN and subjected to western blot analysis. (B) Statistical analysis of BAFF protein content normalized to GAPDH protein content in PBMCs. (C) Concentrations of soluble BAFF protein in plasma were downregulated in patients with IgAN. Diluted plasma samples were detected by ELISA for different groups. (D) The correlation of BAFF mRNA levels with plasma BAFF protein levels. HC, healthy controls; IgAN, patients with IgAN; DC, disease controls (MCD/MN); LN, lupus nephritis. ${ }^{*} \mathrm{P}<0.05,{ }^{* *} \mathrm{P}<0.01,{ }^{* * *} \mathrm{P}<0.001$. BAFF, B cell activation factor; PBMCs, peripheral blood mononuclear cells; IgAN, IgA nephropathy; GAPDH, glyceraldehyde-3-phosphate dehydrogenase; MCD, minimal change disease; MN, membranous nephropathy.
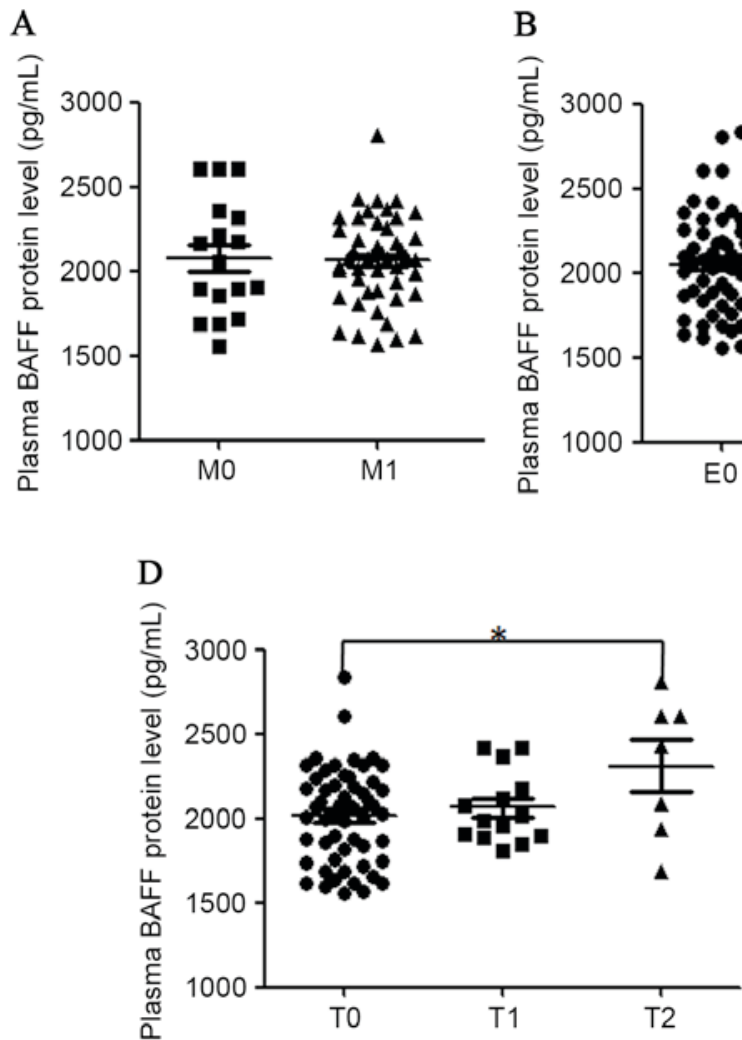
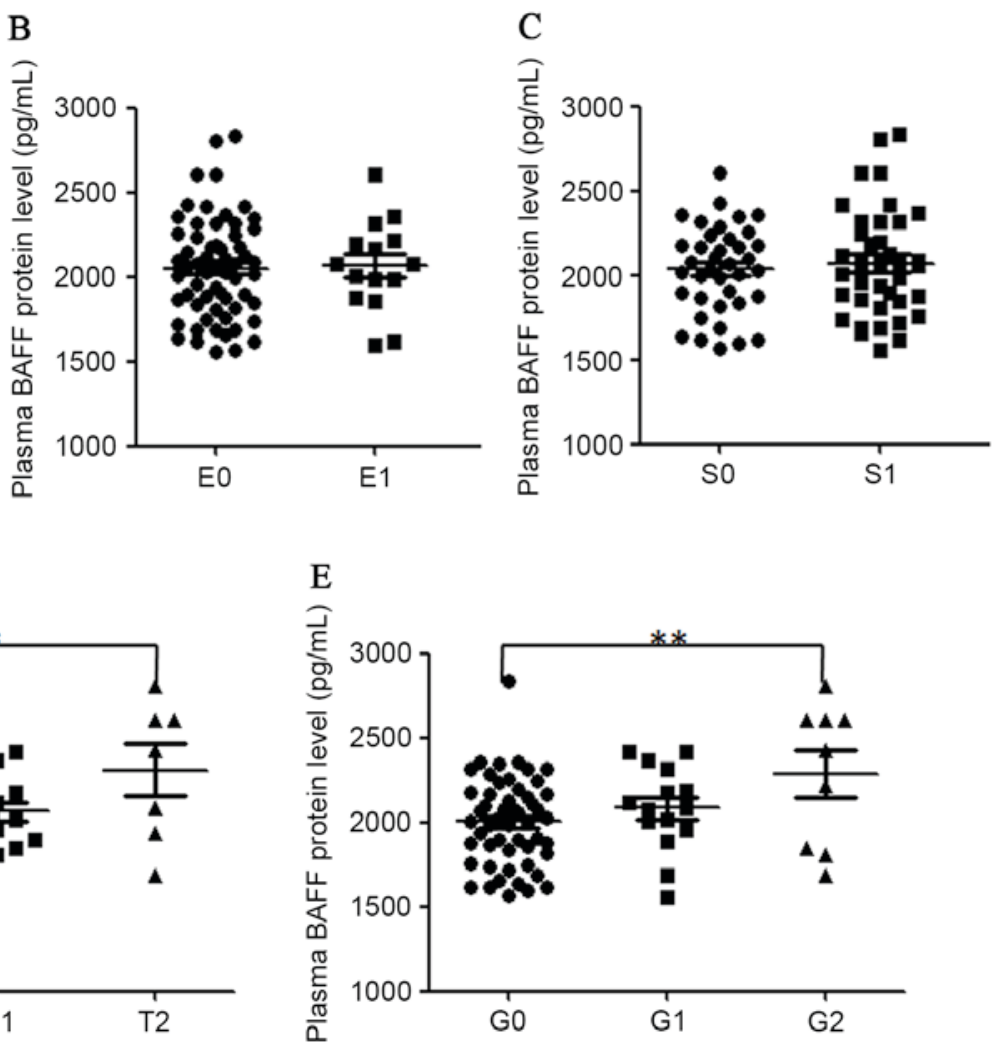

Figure 4. Correlation of plasma levels of BAFF protein with different renal histopathological parameters in patients with IgAN. Plasma BAFF concentrations were classified according to grades (A) M, (B) E, (C) S, (D) T and (E) G. Statistical significance in different groups was analyzed with SPSS software version 18. BAFF, B cell activation factor; IgAN, IgA nephropathy; M, mesangial hypercellularity; S, segmental glomerulosclerosis; E, endocapillary hypercellularity; $\mathrm{T}$, tubular atrophy/interstitial fibrosis; $\mathrm{G}$, portion of global glomerulosclerosis. 
A

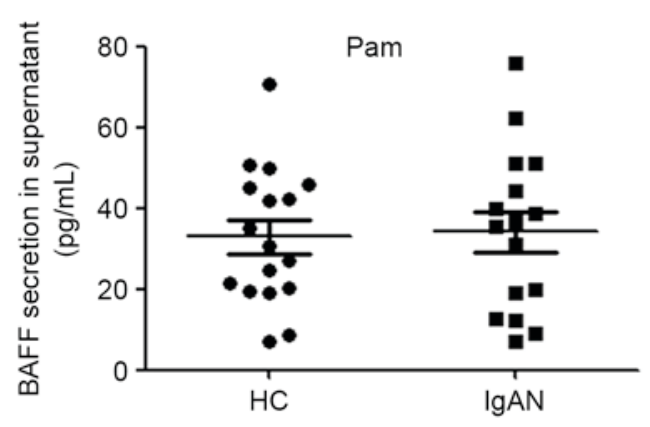

$\mathrm{C}$

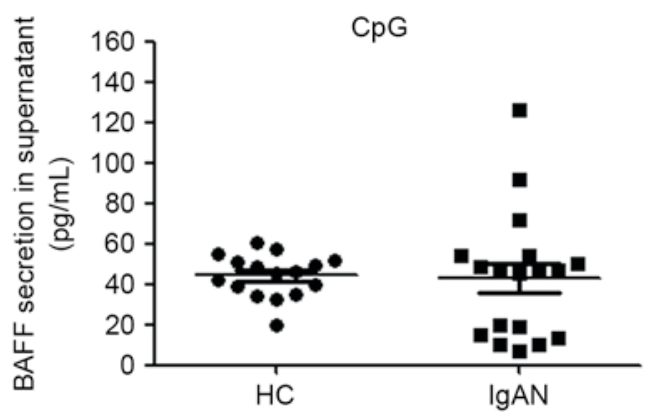

B

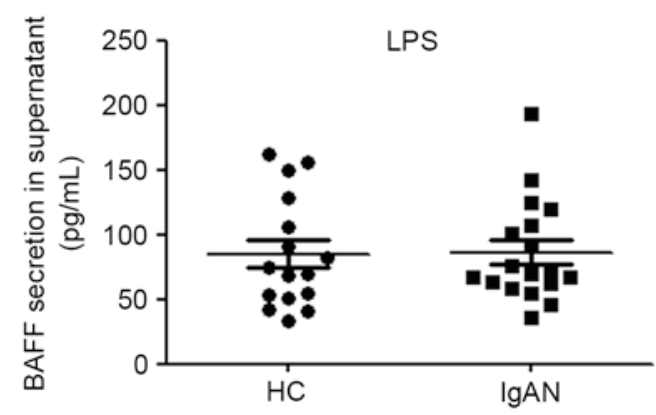

D

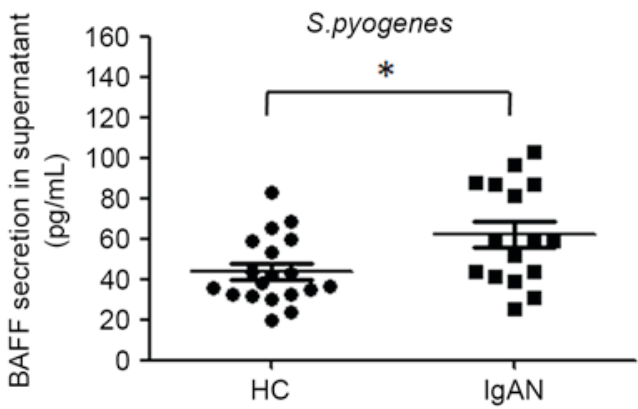

Figure 5. Production of BAFF proteins by PBMCs stimulated with heat-inactivated S. pyogenes and agonists respectively for TLR2, TLR4 and TLR9. PBMCs from healthy controls (HC) and patients with IgAN (IgAN) were cultured for 3 days with (A) Pam3CSK4 (1 $\mu \mathrm{g} / \mathrm{ml}),(\mathrm{B}) \mathrm{LPS}(1 \mu \mathrm{g} / \mathrm{ml}),(\mathrm{C}) \mathrm{CpG} 2395(5 \mu \mathrm{g} / \mathrm{ml})$ and (D) S. pyogenes $\left(2 \times 10^{7} \mathrm{CFU} / \mathrm{ml}\right)$. ${ }^{*} \mathrm{P}<0.05$. BAFF, B cell activation factor; PBMCs, peripheral blood mononuclear cells; TLR, Toll-like receptor; IgAN, IgA nephropathy; LPS, lipopolysaccharide.

glomerulosclerosis. A significant association in plasma BAFF levels and glomerulosclerosis percentile $(r=0.32, \mathrm{P}=0.005)$ in all recruited patients with IgAN was also identified. Plasma BAFF protein levels were not associated with the grade of mesangial hypercellularity, endocapillary hypercellularity or segmental glomerulosclerosis in the kidney samples of patients with IgAN.

The secretion of BAFF proteins from PBMCs of patients with IgAN upon TLRs or $S$. pyogenes stimulation ex vivo. As the mRNA levels of BAFF were closely associated with those of TLRs, and plasma BAFF concentrations were associated with S. pyogenes infection in patients with IgAN, the secretion of BAFF proteins from PBMCs in the presence of TLRs ligands or S.pyogenes stimulation ex vivo was analyzed. TLR7/8 ligand R848 demonstrated very weak stimulatory effect on BAFF secretion in the culture system (data not shown) and therefore was not further investigated in the present study. Activation of TLR2, TLR4 and TLR9 was able to induce BAFF synthesis in PBMCs ex vivo. However, activation of these three TLRs by ligands did not lead to more potent BAFF secretion in patients with IgAN compared with healthy controls (Fig. 5A-C). However, it was demonstrated that heat-inactivated S. pyogenes induced more BAFF production in the PBMCs of patients with IgAN compared with healthy controls $(62.0 \mathrm{pg} / \mathrm{ml} \mathrm{vs}$. $43.9 \mathrm{pg} / \mathrm{ml}, \mathrm{P}=0.015$; Fig. 5D). Furthermore, mRNA levels of BAFF and associated genes were analyzed following stimulation and the result demonstrated that BAFF mRNA level was positively associated with those of BAFF-R $(r=0.50, \mathrm{P}=0.03)$,
TLR2 ( $\mathrm{r}=0.74, \mathrm{P}=0.0002)$, TLR4 $(\mathrm{r}=0.70, \mathrm{P}=0.001)$ and TLR7 $(\mathrm{r}=0.54, \mathrm{P}=0.02)$ in $S$. pyogenes -stimulated PBMCs from patients with IgAN (Fig. 6). A marginal but non-significant correlation between the mRNA levels of BAFF and APRIL $(\mathrm{r}=0.44, \mathrm{P}=0.076)$ was also observed for patients with IgAN following $S$. pyogenes stimulation.

\section{Discussion}

The present study provided detailed data on the abundance of plasma BAFF protein, in addition to BAFF mRNA levels and cellular BAFF protein contents in peripheral blood of patients with IgAN. The data demonstrated that, although BAFF abundance was not higher in the peripheral blood systems of IgAN patients as compared with healthy controls and disease controls, BAFF concentration was closely associated with inflammatory factors, kidney function and renal pathology. The previous data of Xin et al (23) also demonstrated that serum BAFF levels were significantly associated with clinical features and glomerular histopathology in patients with IgAN. However, they identified that BAFF serum levels were elevated in Chinese patients with $\operatorname{IgAN}(23,24)$. One possible reason for this discrepancy is that the present study emphasized that all recruited donors had no clinical symptoms of infection, since infection strongly evokes BAFF expression $(31,35)$ and PBMCs react quickly towards infection. In the present study, all the donors were clear of any symptoms of infection for at least 4 days prior to obtaining the blood samples. Additionally, all donors were followed up for at least 3 days to ensure their 

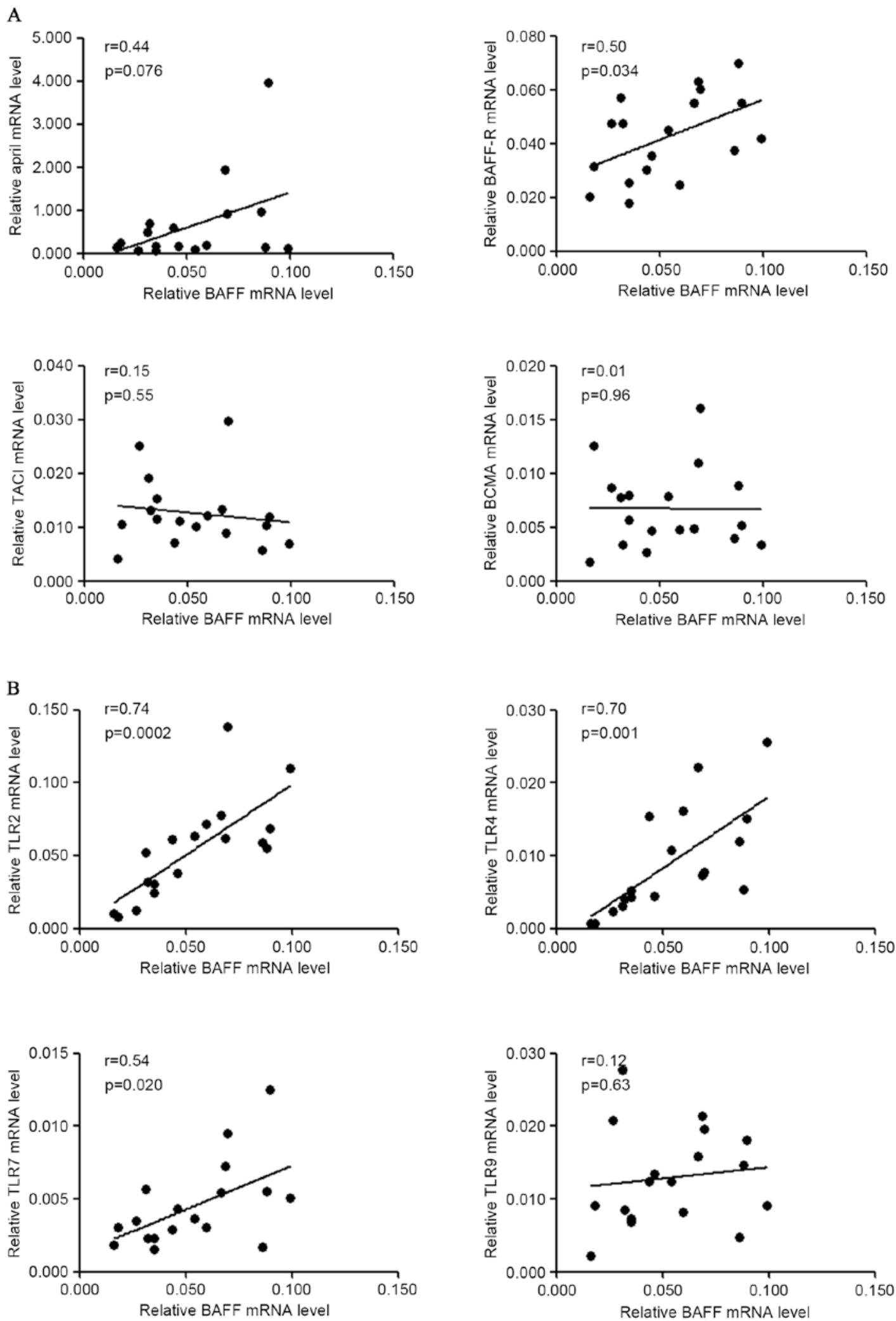

Figure 6. Correlation of gene expression of BAFF and other molecules in PBMCs following S. pyogenes stimulation. PBMCs from patients with IgAN were cultured with heat-inactivated S. pyogenes for $72 \mathrm{~h}$ and RNA was extracted for gene expression analysis. (A) Correlation of BAFF mRNA levels with APRIL, BAFF-R, TACI, BCMA mRNA levels in patients with IgAN. (B) Correlation of BAFF mRNA levels with TLR2, TLR4, TLR7, TLR9 mRNA levels in patients with IgAN. BAFF, B cell activation factor; PBMCs, peripheral blood mononuclear cells; IgAN, IgA nephropathy; APRIL, a proliferation inducing ligand; BAFF-R, BAFF receptor; TACI, transmembrane activator and calcium modulator cyclophilin ligand interactor; BCMA, B cell maturation antigen; TLR, Toll-like receptor.

steady status. The exclusion of active infection allowed the present study to investigate the basal expression levels of
BAFF and associated genes in PBMCs in patients with IgAN. Evidence supporting this is that McCarthy et al (8) tested 
serum BAFF levels in two cohorts (Toronto and Alabama) and they did not observe significant elevation of serum BAFF levels in patients with IgAN when compared with healthy controls.

In the present study, soluble plasma BAFF protein levels were significantly decreased in patients with IgAN while BAFF mRNA levels and cellular BAFF protein levels in PBMCs were not decreased. When interpreting these data, the transcription and later processing of the BAFF gene should be considered. The BAFF gene is translated into two isoforms with distinct functions, in which isoform 1 can exists as a full-length membrane-associated protein or a cleaved short soluble BAFF protein $(11,12,31)$. In quantitative PCR and western blot analysis, all transcript variants/isoforms were targeted for measurement, while in ELISA, only secreted BAFF proteins derived from isoform 1 of the BAFF protein were detected. Another possible explanation is that BAFF proteins are produced by numerous cells throughout the body $(14,36)$, not just peripheral blood cells. The decreased plasma BAFF levels reflect fluctuation within the whole body, not just one local site. Also, the binding of BAFF protein (trimer or 60mers) to its receptors resulted in decreased free BAFF proteins in circulation (13), which possibly happened in IgAN since three receptors of BAFF were all upregulated.

It was identified that BAFF mRNA levels were strongly associated with APRIL mRNA levels in patients with IgAN, in addition to patients with MCD and MN, however not in healthy controls. This result indicated that certain common factors in different types of nephritis regulated the BAFF and APRIL expression with a similar mechanism. Upregulated gene expression of BAFF-R, TACI and BCMA in patients with $\operatorname{IgAN}, \mathrm{MCD}$ and $\mathrm{MN}$ was also detected, which was a new evidence for nephritis. Another novel finding was that in patients with IgAN, gene expression of BAFF was closely associated with those of TLR2, 4 and 7 in PBMCs whether freshly isolated or stimulated by group A Streptococcus, which indicated that BAFF synthesis was closely associated with TLRs abundance in IgAN. He et al (37) identified that TLR3 activation in tonsillar monocytes of patients with IgAN led to enhanced secretion of BAFF and later augmented IgA synthesis.

The connection between IgAN and GAS infection has been reported. The pathogenic antigen of group A Streptococcus-M protein, was detected as deposits in the kidney biopsies of patients with IgAN (38) and provoked the proliferation of IgA-positive B cells in vitro (39). The evidence that Streptococci promoted IgA class-switch recombination in patients with IgAN (40) additionally supported the hypothesis that it was closely associated with B cell dysfunction in IgAN. The present study identified that plasma levels of BAFF protein were positively associated with anti-DNase B titer in patients with $\operatorname{Ig} \mathrm{AN}$, however not in disease controls $(\mathrm{r}=-0.16$, $\mathrm{P}=0.28$ ). More notably, secretion of soluble BAFF proteins was enhanced in the PBMCs of patients with IgAN upon heat-inactivated stimulation with $S$. pyogenes, compared with healthy controls. This result indicated that BAFF synthesis was sensitively controlled by the action of GAS in IgAN, which suggested a novel possible mechanism of IgAN pathogenesis. S. pyogenes usually launches its first attack on the upper respiratory mucosal system, therefore it is possible that the upper respiratory immune system is crucial in regulating BAFF homeostasis in IgAN.

BAFF is expressed by a wide range of cells and organs within the body and its expression is regulated by multiple cytokines and pathogen antigens, in addition to the local inflammatory environment $(22,35,41,42)$. BAFF expression in the PBMCs was a part of the complicated BAFF production system, concurrent with its production in local inflammation sites (43). The present study identified that plasma BAFF levels were positively associated with index of S. pyogenes infection and that the ability of producing BAFF was augmented in PBMCs of patients with IgAN upon being activated by $S$. pyogenes ex vivo. However, the total plasma BAFF levels were significantly decreased in patients with IgAN, which remains to be elucidated. In the case of patients with lupus, the serum BAFF levels were not associated with BAFF mRNA levels in PBMCs, but rather associated with CRP levels $(17,44)$, which also indicated that the origin and regulation of BAFF production was rather complex. To solve this puzzle, the production of BAFF within the whole body and the downstream consumption of BAFF requires careful dissection. However, the way in which the immune system responds to GAS infection remains important for demonstrating the regulation of BAFF synthesis in patients with IgAN.

\section{Acknowledgements}

The present study was supported by the National Natural Science Foundation of China (grant no. 31200664) and the Young Researcher Foundation of Sun Yat-sen University, China (grant no. 14YKPY17).

\section{References}

1. Barratt $\mathrm{J}$ and Feehally J: Primary IgA nephropathy: New insights into pathogenesis. Semin Nephrol 31: 349-360, 2011.

2. Harper SJ, Allen AC, Pringle JH and Feehally J: Increased dimeric IgA producing B cells in the bone marrow in $\operatorname{Ig} \mathrm{A}$ nephropathy determined by in situ hybridisation for $\mathbf{J}$ chain mRNA. J Clin Pathol 49: 38-42, 1996.

3. Boyd JK, Cheung CK, Molyneux K, Feehally J and Barratt J: An update on the pathogenesis and treatment of IgA nephropathy. Kidney Int 81: 833-843, 2012.

4. Nakata J, Suzuki Y, Suzuki H, Sato D, Kano T, Horikoshi S, Novak J and Tomino Y: Experimental evidence of cell dissemination playing a role in pathogenesis of $\operatorname{IgA}$ nephropathy in multiple lymphoid organs. Nephrol Dial Transplant 28: 320-326, 2013.

5. Mackay $\mathrm{F}$ and Ambrose C: The TNF family members BAFF and APRIL: The growing complexity. Cytokine Growth Factor Rev 14: 311-324, 2003.

6. Rolink AG and Melchers F: BAFFled B cells survive and thrive: Roles of BAFF in B-cell development. Curr Opin Immunol 14: 266-275, 2002.

7. Yang M, Hase H, Legarda-Addison D, Varughese L, Seed B and Ting AT: B cell maturation antigen, the receptor for a proliferation-inducing ligand and $\mathrm{B}$ cell-activating factor of the TNF family, induces antigen presentation in B cells. J Immunol 175: 2814-2824, 2005.

8. Mccarthy DD, Kujawa J, Wilson C, Papandile A, Poreci U, Porfilio EA, Ward L, Lawson MA, Macpherson AJ, McCoy KD, et al: Mice overexpressing BAFF develop a commensal flora-dependent, IgA-associated nephropathy. J Clin Invest 121: 3991-4002, 2011.

9. Castigli E, Scott S, Dedeoglu F, Bryce P, Jabara H, Bhan AK, Mizoguchi E and Geha RS: Impaired IgA class switching in APRIL-deficient mice. Proc Natl Acad Sci USA 101: 3903-3908, 2004. 
10. Yu XQ, Li M, Zhang H, Low HQ, Wei X, Wang JQ, Sun LD, Sim KS, Li Y, Foo JN, et al: A genome-wide association study in Han Chinese identifies multiple susceptibility loci for $\operatorname{Ig} \mathrm{A}$ nephropathy. Nat Genet 44: 178-182, 2011.

11. Schneider P, Mackay F, Steiner V, Hofmann K, Bodmer JL, Holler N, Ambrose C, Lawton P, Bixler S, Acha-Orbea H, et al: $\mathrm{BAFF}$, a novel ligand of the tumor necrosis factor family, stimulates B cell growth. J Exp Med 189: 1747-1756, 1999.

12. Gavin AL, Ait-Azzouzene D, Ware CF and Nemazee D DeltaBAFF, an alternate splice isoform that regulates receptor binding and biopresentation of the $\mathrm{B}$ cell survival cytokine, BAFF. J Biol Chem 278: 38220-38228, 2003.

13. Bossen C and Schneider P: BAFF, APRIL and their receptors: Structure, function and signaling. Semin Immunol 18: 263-275, 2006.

14. Mackay F and Schneider P: Cracking the BAFF code. Nat Rev Immunol 9: 491-502, 2009.

15. Vincent FB, Morand EF and Mackay F: BAFF and innate immunity: New therapeutic targets for systemic lupus erythematosus. Immunol Cell Biol 90: 293-303, 2012.

16. Matsushita T and Sato S: The role of BAFF in autoimmune diseases. Nihon Rinsho Meneki Gakkai Kaishi 28: 333-342, 2005 (In Japanese).

17. Eilertsen GO, Van Ghelue M, Strand H and Nossent JC: Increased levels of BAFF in patients with systemic lupus erythematosus are associated with acute-phase reactants, independent of BAFF genetics: A case-control study. Rheumatology (Oxford) 50: 2197-2205, 2011

18. Matsushita T, Hasegawa M, Yanaba K, Kodera M, Takehara K and Sato S: Elevated serum BAFF levels in patients with systemic sclerosis: Enhanced BAFF signaling in systemic sclerosis B lymphocytes. Arthritis Rheum 54: 192-201, 2006.

19. Bosello S, Youinou P, Daridon C, Tolusso B, Bendaoud B, Pietrapertosa D, Morelli A and Ferraccioli G: Concentrations of BAFF correlate with autoantibody levels, clinical disease activity, and response to treatment in early rheumatoid arthritis. J Rheumatol 35: 1256-1264, 2008

20. Mariette X, Roux S, Zhang J, Bengoufa D, Lavie F, Zhou T and Kimberly R: The level of BLyS (BAFF) correlates with the titre of autoantibodies in human Sjögren's syndrome. Ann Rheum Dis 62: 168-171, 2003

21. Pers JO, Daridon C, Devauchelle V, Jousse S, Saraux A, Jamin C and Youinou P: BAFF overexpression is associated with autoantibody production in autoimmune diseases. Ann N Y Acad Sci 1050: 34-39, 2005

22. Moisini I and Davidson A: BAFF: A local and systemic target in autoimmune diseases. Clin Exp Immunol 158: 155-163, 2009.

23. Xin G, Shi W, Xu LX, Su Y, Yan LJ and Li KS: Serum BAFF is elevated in patients with IgA nephropathy and associated with clinical and histopathological features. J Nephrol 26: 683-690, 2013.

24. Li W, Peng X, Liu Y, Liu H, Liu F, He L, Liu Y, Zhang F, Guo C, Chen G, et al: TLR9 and BAFF: Their expression in patients with IgA nephropathy. Mol Med Rep 10: 1469-1474, 2014.

25. Mccarthy DD, Chiu S, Gao Y, Summers-Deluca LE and Gommerman JL: BAFF induces a hyper-IgA syndrome in the intestinal lamina propria concomitant with IgA deposition in the kidney independent of LIGHT. Cell Immunol 241: 85-94, 2006.

26. Working Group of the International Ig A Nephropathy Network and the Renal Pathology Society, Cattran DC, Coppo R, Cook HT, Feehally J, Roberts IS, Troyanov S, Alpers CE, Amore A, Barratt J, et al: The Oxford classification of IgA nephropathy: Rationale, clinicopathological correlations, and classification. Kidney Int 76: 534-545, 2009.

27. Kataoka H, Ohara M, Shibui K, Sato M, Suzuki T, Amemiya N, Watanabe Y, Honda K, Mochizuki T and Nitta K: Overweight and obesity accelerate the progression of $\operatorname{IgA}$ nephropathy: Prognostic utility of a combination of BMI and histopathological parameters. Clin Exp Nephrol 16: 706-712, 2012.
28. Livak KJ and Schmittgen TD: Analysis of relative gene expression data using real-time quantitative PCR and the 2(-Delta Delta C(T)) Method. Methods 25: 402-408, 2001.

29. Liu D, Hollingshead S, Swiatlo E, Lawrence ML and Austin FW: Rapid identification of Streptococcus pyogenes with PCR primers from a putative transcriptional regulator gene. Res Microbiol 156: 564-567, 2005.

30. Parameswaran R, Muschen M, Kim YM, Groffen J and Heisterkamp N: A functional receptor for B-cell-activating factor is expressed on human acute lymphoblastic leukemias. Cancer Res 70: 4346-4356, 2010.

31. Nardelli B, Belvedere O, Roschke V, Moore PA, Olsen HS, Migone TS, Sosnovtseva S, Carrell JA, Feng P, Giri JG and Hilbert DM: Synthesis and release of B-lymphocyte stimulator from myeloid cells. Blood 97: 198-204, 2001

32. Wang XF, Yuan SL, Jiang L, Zhang XL, Li SF, Guo Y, Wu CL and Chen JJ: Changes of serum BAFF and IL-21 levels in patients with systemic lupus erythematosus and their clinical significance. Xi Bao Yu Fen Zi Mian Yi Xue Za Zhi 23: 1041-1042, 2007 (In Chinese)

33. Vincent FB, Northcott M, Hoi A, Mackay F and Morand EF: Association of serum $B$ cell activating factor from the tumour necrosis factor family (BAFF) and a proliferation-inducing ligand (APRIL) with central nervous system and renal disease in systemic lupus erythematosus. Lupus 22: 873-884, 2013.

34. Cunningham MW: Pathogenesis of group A streptococcal infections. Clin Microbiol Rev 13: 470-511, 2000.

35. Huard B, Arlettaz L, Ambrose C, Kindler V, Mauri D, Roosnek E, Tschopp J, Schneider P and French LE: BAFF production by antigen-presenting cells provides $\mathrm{T}$ cell co-stimulation. Int Immunol 16: 467-475, 2004.

36. Schneider P: The role of APRIL and BAFF in lymphocyte activation. Curr Opin Immunol 17: 282-289, 2005.

37. He L, Peng X, Wang J, Tang C, Zhou X, Liu H, Liu F, Sun L and Peng Y: Synthetic double-stranded RNA Poly (I:C) aggravates IgA nephropathy by triggering $\operatorname{Ig}$ A class switching recombination through the TLR3-BAFF axis. Am J Nephrol 42: 185-197, 2015.

38. Schmitt R, Carlsson F, Mörgelin M, Tati R, Lindahl G and Karpman D: Tissue deposits of IgA-binding streptococcal M proteins in IgA nephropathy and Henoch-Schonlein purpura. Am J Pathol 176: 608-618, 2010.

39. Nishikawa Y, Shibata R, Ozono Y, Ichinose H, Miyazaki M, Harada T and Kohno S: Streptococcal M protein enhances TGF-beta production and increases surface IgA-positive B cells in vitro in IgA nephropathy. Nephrol Dial Transplant 15: 772-777, 2000

40. Liu H, Peng Y, Liu F, Xiao W, Zhang Y and Li W: Expression of IgA class switching gene in tonsillar mononuclear cells in patients with IgA nephropathy. Inflamm Res 60: 869-878, 2011.

41. Chu VT, Enghard P, Schurer S, Steinhauser G, Rudolph B, Riemekasten $G$ and Berek C: Systemic activation of the immune system induces aberrant BAFF and APRIL expression in B cells in patients with systemic lupus erythematosus. Arthritis Rheum 60: 2083-2093, 2009.

42. Chen Y, Lind Enoksson S, Johansson C, Karlsson MA, Lundeberg L, Nilsson G, Scheynius A and Karlsson MC: The expression of BAFF, APRIL and TWEAK is altered in eczema skin but not in the circulation of atopic and seborrheic eczema patients. PLoS One 6: e22202, 2011.

43. Nakajima K, Itoh K, Nagatani K, Okawa-Takatsuji M, Fujii T, Kuroki H, Katsuragawa Y, Aotsuka S and Mimori A: Expression of BAFF and BAFF-R in the synovial tissue of patients with rheumatoid arthritis. Scand J Rheumatol 36: 365-372, 2007.

44. Stohl W, Metyas S, Tan SM, Cheema GS, Oamar B, Xu D, Roschke V, Wu Y, Baker KP and Hilbert DM: B lymphocyte stimulator overexpression in patients with systemic lupus erythematosus: Longitudinal observations. Arthritis Rheum 48: 3475-3486, 2003. 